\title{
Increases in Acute Phase Reactants in a Patient with Scurvy Despite No Inflammation: Review of Literature
}

Kaori Kimura ${ }^{1}$, Yasuji Inamo ${ }^{2}$

1. Pediatrics, Nihon University School of Medicine, Tokyo, JPN 2. Pediatrics, Nihon Uniiversity School of Medicine, Tokyo, JPN

$\square$ Corresponding author: Yasuji Inamo, y-inamo@pb3.so-net.ne.jp Disclosures can be found in Additional Information at the end of the article

\section{Abstract}

So far, little attention has been paid to the increase in acute phase reactants (APRs) in patients with scurvy. We report that elevated levels of C-reactive protein (CRP), erythrocyte sedimentation rate (ESR), and serum amyloid A were shown in a pediatric patient with scurvy despite the absence of inflammation. These peculiar findings are important to discriminate scurvy from other rheumatic diseases.

Categories: Pediatrics, Orthopedics, Rheumatology

Keywords: scurvy, vitamin c, c-reactive protein, acute phase reactants, arthritis

\section{Introduction}

An increase in acute phase reactants (APRs) has not been observed in patients with scurvy. In fact, there are few cases of scurvy with descriptive comments on APRs [1]. Pediatric rheumatologists usually measure APRs to evaluate the level of inflammation in patients with leg pain or a limp. Because patients with scurvy complain of leg pain or a limp, it is necessary to discriminate it from other rheumatological diseases. Thus, we aim to discuss why elevated APRs, including C-reactive protein (CRP), in scurvy is an important clinical problem.

\section{Case Presentation}

A 4-year-old male with autism was referred to our hospital because of severe leg pain and gingival bleeding. His laboratory results showed a CRP level of $2.21 \mathrm{mg} / \mathrm{dL}$ (reference range $<0.05 \mathrm{mg} / \mathrm{dL}$ ), a serum amyloid A protein level of $544 \mu \mathrm{g} / \mathrm{ml}$ (reference range $<8 \mu \mathrm{g} / \mathrm{ml}$ ), and an erythrocyte sedimentation rate (ESR) of $94 \mathrm{~mm} /$ hour (reference range 5-15

Received 01/25/2019 Review began 01/29/2019 Review ended 09/03/2019 Published 09/09/2019

\section{(c) Copyright 2019}

Kimura et al. This is an open access article distributed under the terms of the Creative Commons Attribution License CC-BY 3.0., which permits unrestricted use, distribution, and reproduction in any medium, provided the original author and source are credited. $\mathrm{mm}$ /hour). His leg pain did not subside with acetaminophen. His physical symptoms and APRs improved quickly on the administration of vitamin $\mathrm{C}$ after a diagnosis of scurvy.

\section{Discussion}

Although several reports have described the levels of elevated CRP, ESR, and serum amyloid A, they have not garnered enough attention (Table 1) [1-7]. The peculiar findings could be misleading as an inflammatory reaction. But, an increase in acute phase reactants (APRs) in scurvy should be recognized as a common phenomenon. 


\section{Cureus}

\begin{tabular}{|c|c|c|c|c|}
\hline Case no. (from references of citation) & Age (year) & CRP (mg/L) & ESR (mm/hour) & Reference \\
\hline sex, (reference range) & $\square$ & $\square$ & $\square$ & $\square$ \\
\hline 1 & 26 & 4 & 41 & [1] \\
\hline$\square$ & male & $\left(N D^{* *}\right)$ & $\left(N D^{* *}\right)$ & $\square$ \\
\hline 2 & 22 & 13.4 & 101 & [1] \\
\hline$\square$ & male & $\left(N D^{* *}\right)$ & $\left(N D^{* *}\right)$ & $\square$ \\
\hline 3 & 74 & $N D^{* *}$ & 41 & [1] \\
\hline$\square$ & female & $\square$ & $\left(N D^{* *}\right)$ & $\square$ \\
\hline 4 & 6 & 31.1 & 103 & [2] \\
\hline$\square$ & male & $(0.1-1)$ & $(2-34)$ & $\square$ \\
\hline 5 & 9 & 24.5 & 59 & [3] \\
\hline$\square$ & male & $(<8.0)$ & $(0-17)$ & $\square$ \\
\hline 6 & 12 & almost normal $^{*}$ & 44 & [4] \\
\hline$\square$ & male & $\square$ & $(0-15)$ & $\square$ \\
\hline 7 & 9 & 1.3 & 23 & [5] \\
\hline$\square$ & male & $(<0.5)$ & $(0-20)$ & $\square$ \\
\hline 8 & 5 & 5.81 & 44 & [6] \\
\hline$\square$ & male & $(<0.3)$ & $(0-15)$ & $\square$ \\
\hline 9 & 10 & 10.9 & $N D^{\star *}$ & [7] \\
\hline$\square$ & male & $(<1)$ & $\square$ & $\square$ \\
\hline Our case & 4 & 22.1 & 94 & \\
\hline$\square$ & male & $(<0.5)$ & $(5-15)$ & $\square$ \\
\hline
\end{tabular}

\section{TABLE 1: Results of laboratory tests on CRP and ESR in patients with scurvy}

${ }^{*}$ Described as almost normal on the article. ${ }^{* *}$ ND: not described

CRP; C-reactive protein, ESR; erythrocyte sedimentation rate

It is difficult to interpret elevations in APRs that are caused by local bone lesions in scurvy, which, by radiology, are reflected by increases in zones of provisional calcification in the margins of the growth plate. Conversely, CRP does not increase in vitamin D deficiency rickets, which appears in radiological findings as a failure of mineralization in such zones. The levels of APRs fall after the administration of vitamin C, but anti-inflammatory drugs do not have the 
same effect. Therefore, it is difficult to conclude that inflammation due to scurvy induces a rise in APRs.

It is well-known that plasma vitamin C is inversely related to CRP [8]. Both, the low levels of serum vitamin $\mathrm{C}$ and the levels of elevated CRP, may participate in atherothrombosis and ischemic heart disease. However, the levels of CRP in scurvy are higher than those in atherosclerosis. Only CRP, apart from the other APRs, increases in atherosclerosis. The source of CRP in scurvy might be different from the vascular endothelial site in atherosclerosis. Vitamin C deficient rats without inflammatory stimuli experience an increase in APRs, which are produced in the liver [9-10]. Although the mechanism by which APRs are elevated in scurvy remains unknown, these rats can provide vital clues for elucidating it.

We believe that a deficiency of serum vitamin C itself can generate APRs, to resemble an aspect of inflammatory biomarkers. The specific findings are important to discriminate scurvy from any other rheumatic diseases with an inflammatory reaction.

\section{Conclusions}

We conclude that the depletion of vitamin C (i.e., scurvy) leads to the production of APRs in the liver, the laboratory results for which resemble acute inflammation despite a lack of inflammation.

\section{Additional Information \\ Disclosures}

Human subjects: Consent was obtained by all participants in this study. Conflicts of interest: In compliance with the ICMJE uniform disclosure form, all authors declare the following:

Payment/services info: All authors have declared that no financial support was received from any organization for the submitted work. Financial relationships: All authors have declared that they have no financial relationships at present or within the previous three years with any organizations that might have an interest in the submitted work. Other relationships: All authors have declared that there are no other relationships or activities that could appear to have influenced the submitted work.

\section{References}

1. Mertens MT, Gertner E: Rheumatic manifestations of scurvy: a report of three recent cases in a major urban center and a review. Semin Arthritis Rheum. 2011, 41:286-290.

10.1016/j.semarthrit.2010.10.005

2. Erdle S, Conway M, Weinstein M: A six-year-old boy with autism and left hip pain . CMAJ. 2017, 189:275-278. 10.1503/cmaj.160712

3. Duggan CP, Westra SJ, Rosenberg AE: Case records of the Massachusetts General Hospital. Case 23-2007. A 9-year-old boy with bone pain, rash, and gingival hypertrophy. N Engl J Med. 2007, 357:392-400. 10.1056/NEJMcpc079017

4. Alqanatish JT, Alqahtani F, Alsewairi WM, Al-kenaizan S: Childhood scurvy: an unusual cause of refusal to walk in a child. Pediatr Rheumatol Online J. 2015, 13:23. 10.1186/s12969-0150020-1

5. Rana J, Alterkait A, Weinstein M: Picture of the month-quiz case . Arch Pediatr Adolesc Med. 2012, 166:479-480. 10.1001/archpediatrics.2011.1247a

6. Duvall MG, Pikman Y, Kantor DB, Ariagno K, Summers L, Sectish TC, Mullen MP: Pulmonary hypertension associated with scurvy and vitamin deficiencies in an autistic child. Pediatrics. 2013, 132:1699-1703. 10.1542/peds.2012-3054

7. Noble JM, Mandel A, Patterson MC: Scurvy and rickets masked by chronic neurologic illness: revisiting "psychologic malnutrition". Pediatrics. 2007, 119:783-790. 10.1542/peds.2006-1071

8. Wannamethee SG, Lowe GD, Rumley A, Bruckdorfer KR, Whincup PH: Associations of vitamin 


\section{Cureus}

C status, fruit and vegetable intakes, and markers of inflammation and hemostasis. Am J Clin Nutr. 2006, 83:567-574. 10.1093/ajcn.83.3.567

9. Ikeda S, Horio F, Kakinuma A: Ascorbic acid deficiency changes hepatic gene expression of acute phase proteins in scurvy-prone ODS rats. J Nutr. 1998, 128:832-838.

10.1093/jn/128.5.832

10. Horio F, Kiyama K, Kobayashi M, Kawai K, Tsuda T: Ascorbic acid deficiency stimulates hepatic expression of inflammatory chemokine, cytokine-induced neutrophil chemoattractant-1, in scurvy-prone ODS rats. J Nutr Sci Vitaminol (Tokyo). 2006, 52:28-32. $10.3177 /$ jnsv. 52.28 